\title{
Management of Euxesta spp. in Sweet Corn with McPhail Traps
}

\author{
SR LOPES, I CRUZ \\ Embrapa Milho e Sorgo, Sete Lagoas, MG, Brasil
}

\section{Keywords}

Bio Anastrepha ${ }^{\circledR}$, food attractant, maize ear fly, natural control, traps

\section{Correspondence}

I Cruz, Embrapa Milho e Sorgo, Sete Lagoas, 35701-970, MG, Brasil; ivan.cruz@embrapa. br

Edited by Rafael M Pitta - Embrapa

Received 5 June 2019 and accepted 22 October 2019

Published online: 8December 2019

(C) Sociedade Entomológica do Brasil 2019

\begin{abstract}
Pests attacking the ear of sweet corn, such as Helicoverpa and Euxesta species, cause economic losses for the producer and the processing industry. Feeding on the style-stigmata preventing fertilization and on the developing grain and the association with pathogens are the main causes of product depreciation. The traditional control such as spraying with chemicals is not effective, even with several applications directed to the corn ear. Bacillus thuringiensis (Bt) corn also does not reach the fly. McPhail traps that have been used to monitor the pest can be a control strategy. This work evaluated the efficiency of food attractants placed inside McPhail traps to remove adult insects, in order to reduce ear damage. Twelve McPhail-type traps were installed in a randomized complete block design containing Bio Anastrepha ${ }^{\circledR}$ alone or combined with different doses of insecticide. Every 10 days, all the captured insects were counted and separated by species and sex. Only Euxesta eluta and Euxesta mazorca were found. The occurrence of insects was greater in the period between silk emergence and grain filling. The number of females was higher, probably due to the need to feed before oviposition. The number of $E$. mazorca females caught in the treatment containing only Bio Anastrepha ${ }^{\circledR}$ was higher compared with that of others. The mean ear damage was very low, and there was no interaction between the production parameters and the distance between the trap and the harvested plant. In short, the use of McPhail trap containing food attractants may be a viable alternative to control corn silk flies.
\end{abstract}

\section{Introduction}

Sweet corn is a "special crop" in Brazil, and all production is destined to canned food companies. This market has been growing in recent years, especially when it comes to exports (Figueiredo et al 2015). The same insect species that attack conventional grain corn can be found in sweet corn. However, sweet corn is known to be more susceptible to phytophagous insects. According to Cruz et al (1999), maize yield reductions due to Spodoptera frugiperda (J.E. Smith) leaf damage were $57.6,28.9$, and $21 \%$, for insect feeding on a sweet maize BR 400 , a white high-quality protein maize BR 451 , and a conventional yellow maize BR 201, respectively.

Reduction on the quality of the ear due to requirements of the processing industry may occur by insect damage directly to the grains. Injuries caused to the tip of the ear may not cause so much damage to the industry as they can be mechanically eliminated in processing. However, when damage occurs along the ear, caused by Lepidoptera and ear fly larvae, the loss in this case is total for the industry.

The sweet corn pests with the greatest potential to cause injury and, consequently, to cause losses to both the agricultural and industrial sectors are those that affect specifically the ear, such as the Lepidoptera larvae S. frugiperda and Helicoverpa complex, which also cause leaf damage, and Euxesta spp. (Diptera) (Cruz et al 2016). Insects feeding on corn ears are usually sheltered from conventional pest control technologies such as chemical application. There is also the possibility of unacceptable residues in the harvest product. Even the use of transgenic maize 
(Bacillus thuringiensis [Bt] maize) has not been an alternative, due to non-acceptance by consumers. Therefore, there is a need for new low-cost, efficient control technologies to increase field and industrial yield. For Lepidoptera species, biological control has been successfully performed by releasing egg parasitoids such as Trichogramma spp. (Figueiredo et al 2015, Cruz et al 2016). Unfortunately, there is still no technology to control efficiently the corn silk fly while providing residue-free grain.

The damage caused by the fly is a consequence of the injury caused by the larvae initially feeding on the silk (thus reducing pollination and consequently fertilization) and then attacking the grains in the milk stage, reducing the quality and yield of the crop (Frias 1981; Painter 1985; Branco et al 1994). The problem is exacerbated by the attempt to control with chemical insecticides, since the high number of applications leads to an increase in the concentration of chemical residues in the final product. Pesticide residues above the maximum residue limits allowed by the law constitute a barrier to processed food exports (Figueiredo et al 2015).

In one of the first Brazilian works in the field, Cruz et al (2011) demonstrated the efficiency of different food attractants associated with McPhail traps to monitor Euxesta spp. in maize areas, which would allow its use for pest management. In the same work, the authors reported for the first time in the country the presence of Euxesta mazorca in ears of corn.

Considering the lack of adequate control methods, the main objective of this work was to evaluate the use of McPhail traps containing food attractants to remove corn silk flies in sweet corn fields, in order to reduce kernel damage and yield losses caused by the pest in field conditions; ensure product quality, and therefore, increase processing yield; and minimize the environmental impacts and residues in food caused by chemical pesticides, making use of clean technology and Good Agricultural Practices.

\section{Materials and Methods}

The work was conducted at a sweet corn seed production area of the Brazilian National Maize and Sorghum Research Center, located in the municipality of Sete Lagoas, Minas Gerais State, Brazil (coordinates $19^{\circ} 28^{\prime} 45^{\prime \prime} \mathrm{S}$ and $44^{\circ} 10^{\prime} \mathrm{O} 8^{\prime \prime} \mathrm{W}$ ). The planting of sweet corn seeds took place in February 25, in an area of 0.8 ha under the central pivot irrigation system. Pest control in the area is carried out mainly for Lepidoptera species, notably Spodoptera frugiperda (Smith) and Helicoverpa zea (Boddie) by releasing the egg parasitoid Trichogramma pretiosum Riley (Figueiredo et al 2015).

To capture Euxesta spp., we installed $12 \mathrm{McPhail}$ traps in April 7, when plants were in the vegetative stage 7 (V7) according to Ciampitti et al (2011). The traps were hung by a wood pole $1.2 \mathrm{~m}$ above the ground and spaced 30 and $22 \mathrm{~m}$ apart (vertical and horizontal directions, respectively), covering an area of $666.7 \mathrm{~m}^{2}$ (Fig 1). The experiment was carried out in a randomized block design with four treatments, each with three replicates. The treatments were as follows: (I) food attractant Bio Anastrepha ${ }^{\circledR}$; (II) Bio Anastrepha ${ }^{\circledR}+1.5 \mathrm{~mL}$ Karate 50 CS (lambda-cyhalothrin; Syngenta); (III) Bio Anastrepha ${ }^{\circledR}+2.25 \mathrm{~mL}$ Karate $50 \mathrm{CS}$; (IV) Bio Anastrepha ${ }^{\circledR}+3.0 \mathrm{~mL}$ Karate $50 \mathrm{CS}$. The commercial product is efficient, low cost and toxicological class III (moderately toxic), and legally registered for use on maize spraying especially for Lepidoptera control. According to Nuessly and Hentz (2004), relatively low doses of pyrethroids, although causing a low initial mortality rate, had enough sublethal effect to almost completely immobilized adult insects after just $1 \mathrm{~h}$ of exposure; however, causing 95\% mortality with $2 \mathrm{~h}$ of exposure. Subsequently, Owens et al (2016b) demonstrated that both Chaetopsis massyla Walker and Euxesta stigmatias recover soon after applying different pyrethroid treatments.

All traps received the food attractant Bio Anastrepha ${ }^{\circledR}$, whose efficiency has already been verified (Cruz et al 2011). The commercial product was first diluted in water to a final concentration of $5 \%$; then, aliquots of $1.2 \mathrm{~L}$ were taken out. For treatments II, III, and IV, we added 1.5, 2.25, and $3.0 \mathrm{~mL}$, respectively, of the commercial insecticide with lambdacyhalothrin ( $50 \mathrm{~g} \mathrm{~L}^{-1}$ ). Afterwards, $400 \mathrm{~mL}$ of each aliquot was transferred to three separate vials (plastic bottles), and the liquid solution without the addition of any preservatives was placed inside at the base of the McPhail trap and soon after covered by a clear plastic lid; this way, the air intake was only through the bottom of the traps.

Nine evaluations of the presence of captured insects occurred, with a 10-day interval, starting 10 days after placing the traps, that is, 45 days after plant emergence. Similar ranges had already been used (Cruz et al 2011), and in this experiment, no significant physical loss of the flies was verified either; therefore, no preservatives were used. After each evaluation, the traps were washed and refilled with new $400 \mathrm{ml}$ of the solution; although, in this period, there was no drying of the diluted BioAnastrepha solution. In each evaluation, the captured insects were placed in 500-mL bottles, taken to the laboratory, and immediately counted after being separated by species and by sex. The task of insect counting and sex separation was relatively easy to perform since the insects remained well preserved within the McPhail trap as the solution drying was very low. Morphological characteristics, such as wing color and the presence of ovipositor in females (Steyskal 1968, 1974; Huepe et al 1986), were the identification tool parameters to separate sex and species of Euxesta. At the end of the evaluation, the insects were deposited at the Embrapa Entomology Museum in Sete Lagoas, Brazil. 
When in R3, we harvested a total of the 36 ears around the traps at $1 \mathrm{~m}$ and $10.2 \mathrm{~m}$ on the left and right sides and at $15 \mathrm{~m}$ both forward and backwards (Fig 1). All ears were individually husked, weighted, and measured; they were also evaluated in relation to insect damage at the tip or in the middle of the ear. Later, they were threshed to obtain grain weight. Statistical analysis was performed in the SISVAR statistical program (Sistema Sisvar 2017). The available data were submitted to analysis of variance (ANOVA), and means were compared using the Scott-Knott test $(P<0.05)$ (Scott \& Knott 1974).

\section{Results}

Only Euxesta eluta and E. mazorca were found in the sweet corn fields, in accordance with Cruz et al (2011). The total number of captured adult flies, considering all traps placed in the field, was 51,051. From those, we were able to identify the sex of 50,702 insects, distributed in all evaluation times, which shows the presence of the species during almost all stages of development of the plant, as reported by Frias (1981). This presence was easily verified soon after the deployment of the traps and at each food attractant solution change.

The data in Table 1 show significant difference in the mean of captured insects when considering all traps and treatments. The number of collected females from E. mazorca was significantly higher, with a mean of 230.3 insects per trap, followed by $E$. eluta females, also with relatively high numbers (187.9 individuals per trap). The number of males from both species was significantly lower than the number of

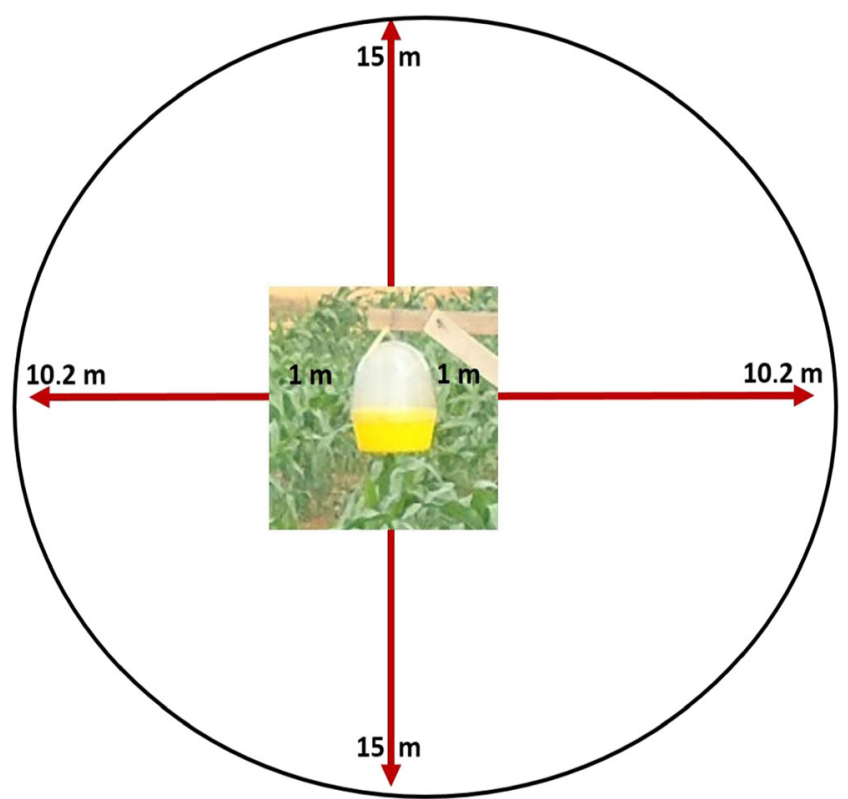

Fig 1 Maize ears harvesting sites (distance from the center of the trap). females, and there were no significant differences between the means obtained, 43.05 and 19.3 male insects of $E$. eluta and $E$. mazorca, respectively. These averages represent, respectively, 22.9 and $8.8 \%$ of the number of captured females, indicating that females are much more attracted to this food source. This is probably due to the female's need to feed before oviposition.

The mean number of $E$. eluta males in the 4 th and 5 th samples (154.1 and 105, respectively) is statistically higher than the number of males from the very same species captured in the other dates (Table 1). Similar trend occurred in relation to females. In the fifth sample, the number of E. eluta females was significantly higher than the rest, with a mean of 722.2 females per trap. The second highest mean we found was in the 4 th sampling time, with 369.6 females per traps, which means that the number of captured females from this species nearly doubled in a 10-day interval.

There was no significant difference in the number of E. mazorca males between surveys. For females, there were significant differences between the samples. The capture peak occurred in the fourth sampling date, with a mean of 648.8 females per trap. This peak occurred 10 days before the E. eluta peak, which was in the fifth sample. In fact, there was a reversal in the female population, since the second highest peak of $E$. mazorca females occurred at the same as the main E. eluta peak.

The peaks on the capture of females in the fourth and fifth sampling, respectively, 40 and 50 days after plant emergence overlap the beginning of flowering in the crop. This may explain the peak for both species' populations, considering the number of captured females in the first three sampling dates (175.5 females per trap) much smaller than in the fourth and fifth sampling times (1141.8), in the case of E. eluta. For E. mazorca, those values were 207.6 and 1100.6 females, respectively. The stage of greater susceptibility of the plants has most likely functioned as the principal attractor of the insect from greater distances. Within the planting area, the food attractant solution had great importance in attracting females. It was able to remove a significant number of insects from the area, helping reduce the number of deposited eggs on the plant, especially considering that an adult can live up to 100 days.

The results shown in Table 2 indicate that there was no influence of the addition of different doses of the lambdacyhalothrin insecticide on male capture of both $E$. eluta and E. mazorca. The insecticide may have had repellent action contrary to what happened with the capture of females. For the $E$. eluta, there was no significant difference between the number of females caught in traps containing only the food attractant (239.4 females) or with Bio Anastrepha ${ }^{\circledR}+1.5 \mathrm{~mL}$ lowest dose of insecticide (204.4 females). These means were significantly different from those obtained in treatments with $2.25 \mathrm{~mL}$ (154.2 females) and $3.0 \mathrm{~mL}$ (153.7 females) of 
Table 1 Mean number $( \pm$ SE) of Euxesta spp. male and female adults collected by McPhail-type traps in different sampling dates, Sete Lagoas, Brazil.

\begin{tabular}{|c|c|c|c|c|}
\hline \multirow[t]{2}{*}{ Days after plant emergence } & \multicolumn{2}{|l|}{ Euxesta eluta } & \multicolumn{2}{|c|}{ Euxesta mazorca } \\
\hline & Male & Female & Male & Female \\
\hline 45 & $21.6 \pm 9.0 \mathrm{Oa}$ & $36.5 \pm 2.8 \mathrm{Ca}$ & $3.4 \pm 0.5 \mathrm{Aa}$ & $16.9 \pm 06 \mathrm{Ea}$ \\
\hline 55 & $23.5 \pm 2.9 \mathrm{Ba}$ & $53.7 \pm 4.0 \mathrm{Ca}$ & $13.3 \pm 1.6 \mathrm{Aa}$ & $64.4 \pm 4.6 \mathrm{Ea}$ \\
\hline 65 & $16.2 \pm 1.3 \mathrm{Bb}$ & $85.3 \pm 7.3 \mathrm{Ca}$ & $16.8 \pm 2.1 \mathrm{Ab}$ & $126.3 \pm 17.6 \mathrm{Da}$ \\
\hline 75 & $154.1 \pm 77.9 \mathrm{Ac}$ & $369.6 \pm 46.7 \mathrm{Bb}$ & $44.9 \pm 4.0 \mathrm{Ad}$ & $648.8 \pm 81.3 \mathrm{Aa}$ \\
\hline 85 & $105.1 \pm 9.0 \mathrm{Ac}$ & $772.2 \pm 55.3 \mathrm{Aa}$ & $45.2 \pm 1.1 \mathrm{Ac}$ & $451.8 \pm 64.1 \mathrm{Bb}$ \\
\hline 95 & $8.6 \pm 1.1 \mathrm{Bb}$ & $57.16 \pm 4.1 \mathrm{Cb}$ & $16.5 \pm 0.6 \mathrm{Ab}$ & $118.2 \pm 10.6 \mathrm{Da}$ \\
\hline 105 & $10.5 \pm 1.2 \mathrm{Bb}$ & $73.9 \pm 2.0 \mathrm{Ca}$ & $8.9 \pm 3.3 \mathrm{Ab}$ & $144.6 \pm 44.7 \mathrm{Da}$ \\
\hline 115 & $21.7 \pm 1.7 \mathrm{BC}$ & $121.3 \pm 5.0 \mathrm{Cb}$ & $12.25 \pm 3.6 \mathrm{Ac}$ & $243.4 \pm 29.5 \mathrm{Ca}$ \\
\hline 125 & $25.8 \pm 1.7 \mathrm{Bb}$ & $121.2 \pm 8.7 \mathrm{Ca}$ & $12.6 \pm 4.1 \mathrm{Ab}$ & $168 \pm 67.7 \mathrm{Da}$ \\
\hline Average & $43.05 c$ & $187.9 \mathrm{~b}$ & $19.3 \mathrm{C}$ & $220.3 a$ \\
\hline
\end{tabular}

Means followed by the same uppercase letter in columns and lowercase letter in rows do not differ significantly by Scott-Knott test $(P<0.05)$.

insecticide. The latter two means did not differ significantly from each other. Owens et al (2016a) reported positive effect in preventing damage to corn cob due to fall armyworm, S. frugiperda and ulidiid flies after spraying a chemical mixed with food attractant.

For E. mazorca, the highest number of females was observed in the traps containing only the food attractant ( 357.8 females). This mean differed significantly from the others. There was no significant difference between the means of females caught in traps with the chemical, whose values were, in increasing order of dose, 191.2, 177.9, and 154.1 females per trap. In comparative terms, considering the means of females of these three treatments (174.4 females), traps with only the food attractant captured twice as many females.

Considering all insects regardless of sex and species, there was clearly a negative effect of adding the chemical to the food attractant, probably due to repellency (Table 3). Considering data from all sampling times, the mean number of captured insects in control (168.2 insects) was significantly higher than the mean number in the traps with the addition of insecticide (100.6 insects).
The females of E. mazorca accounted for $92.35 \%$ of the total number of individuals caught in this species $(25,764)$, whereas for the E. eluta species, they represented $81.35 \%$ of the total of 24,938 individuals captured. Figure 2 shows the total number of insects from both species and in each sampling time, considering all traps. Sixty-one percent of the total number of females was caught between the fourth and fifth sampling dates, that is, a high incidence in the target area at the time of maize flowering. Before the period of greatest capture, the number of females represented only $10.44 \%$ of the total; in the last four evaluations, this value was $28.51 \%$.

Regarding females, we can see the rapid increase in the number of collected insects starting from the third sampling date, with E. mazorca reaching its population peak before E. eluta. Overall, the number of females was impressive for both species considering the size of the sweet corn planting.

Removal of the pests would only have practical value if there was a significant reduction in the damage caused to the ears. The results shown in Tables 4 and 5 indicate that there was no significant difference in production variables or in the mean damage caused by the pest regardless of the attack site. There was no significant difference in cob weight and length, insect damage at the tip or in middle of the cob, or in grain

Table 2 Mean number $( \pm$ SE) of Euxesta spp. male and female adults collected by McPhail-type traps with different treatments, Sete Lagoas, Brazil.

\begin{tabular}{|c|c|c|c|c|}
\hline \multirow[t]{2}{*}{ Treatment } & \multicolumn{2}{|l|}{ Euxesta eluta } & \multicolumn{2}{|c|}{ Euxesta mazorca } \\
\hline & Male & Female & Male & Female \\
\hline Bio Anastrepha & $46.4 \pm 5.3 A c$ & $239.4 \pm 31.6 \mathrm{Ab}$ & $29.3 \pm 3.6 \mathrm{Ac}$ & $357.8 \pm 42.2 \mathrm{Aa}$ \\
\hline Bio Anastrepha + $1.5 \mathrm{~mL}$ & $26.3 \pm 3.2 \mathrm{Ab}$ & $204.4 \pm 28.2 \mathrm{Aa}$ & $16.2 \pm 1.9 \mathrm{Ab}$ & $191.2 \pm 25.5 \mathrm{Ba}$ \\
\hline Bio Anastrepha $+2.25 \mathrm{~mL}$ & $36.1 \pm 4.8 \mathrm{Ab}$ & $154 \pm 20.2 \mathrm{Ba}$ & $16.7 \pm 1.9 \mathrm{Ab}$ & $177.9 \pm 21.6 \mathrm{Ba}$ \\
\hline Bio Anastrepha + $3.0 \mathrm{~mL}$ & $63.4 \pm 9.8 \mathrm{Ab}$ & $153.7 \pm 21.6 \mathrm{Ba}$ & $15.2 \pm 1.8 \mathrm{Ab}$ & $154.1 \pm 20.6 \mathrm{Ba}$ \\
\hline Average & $43.1 \pm 7.9 \mathrm{c}$ & $187.9 \pm 20.9 b$ & $19.3 \pm 3.7 c$ & $220.3 \pm 46.2 a$ \\
\hline
\end{tabular}

Means followed by the same uppercase letter in columns and lowercase letter in rows do not differ significantly by Scott-Knott test $(P<0.05)$. 
Table 3 Mean number $( \pm \mathrm{SE}$ ) of Euxesta spp. adults collected by McPhail-type traps with different treatments in different sampling times, Sete Lagoas, Brazil.

\begin{tabular}{|c|c|c|c|c|c|}
\hline \multirow[t]{2}{*}{ Days after plant emergence } & \multicolumn{4}{|c|}{ Treatments (food attractant + amount of insecticide) } & \multirow[t]{2}{*}{ Average } \\
\hline & Bio Anastrepha ${ }^{\circledast}$ & Bio Anastrepha ${ }^{\circledast}+1.5 \mathrm{~mL}$ & Bio Anastrepha ${ }^{\circledast}+2.25 \mathrm{~mL}$ & Bio Anastrepha ${ }^{\oplus}+3.0 \mathrm{~mL}$ & \\
\hline 45 & $33.1 \pm 10.0 \mathrm{Ba}$ & $16.1 \pm 6.6 \mathrm{Ba}$ & $13.7 \pm 5.7 \mathrm{Ba}$ & $15.5 \pm 6.0 \mathrm{Ba}$ & $19.6 \mathrm{D}$ \\
\hline 55 & $79.2 \pm 25.1 \mathrm{Ba}$ & $23.2 \pm 8.7 \mathrm{Ba}$ & $31.7 \pm 9.7 \mathrm{Ba}$ & $20.9 \pm 5.8 \mathrm{Ba}$ & $38.7 \mathrm{D}$ \\
\hline 65 & $100.2 \pm 45.9 \mathrm{Ba}$ & $58.5 \pm 25.9 \mathrm{Ba}$ & $61.1 \pm 25.4 \mathrm{Ba}$ & $24.9 \pm 11.4 \mathrm{Ba}$ & $61.2 \mathrm{D}$ \\
\hline 75 & $392.7 \pm 209.5 \mathrm{Aa}$ & $334.7 \pm 171.6 \mathrm{Aa}$ & $211.7 \pm 92.9 \mathrm{Ab}$ & $278.3 \pm 107.7 \mathrm{Ab}$ & $304.4 B$ \\
\hline 85 & $438 \pm 196$ Aa & $315.7 \pm 163.9 \mathrm{Ab}$ & $285.2 \pm 139.9 \mathrm{Ab}$ & $335.6 \pm 182.6 \mathrm{Ab}$ & $343.6 \mathrm{~A}$ \\
\hline 95 & $78.2 \pm 43.4 \mathrm{Ba}$ & $44 \pm 22.4 \mathrm{Ba}$ & $37.66 \pm 21.9 \mathrm{Ba}$ & $32.41 \pm 16.9 \mathrm{Ba}$ & $50.2 \mathrm{D}$ \\
\hline 105 & $108.9 \pm 71.7 \mathrm{Ba}$ & $44.8 \pm 22.4 \mathrm{Ba}$ & $40.8 \pm 18.1 \mathrm{Ba}$ & $43.5 \pm 20.8 \mathrm{Ba}$ & $59.5 \mathrm{D}$ \\
\hline 115 & $114.2 \pm 57.5 \mathrm{Ba}$ & $88.6 \pm 45.4 \mathrm{Ba}$ & $120.3 \pm 73.5 \mathrm{Ba}$ & $75.6 \pm 42.0 \mathrm{Ba}$ & $99.7 \mathrm{C}$ \\
\hline 125 & $169.6 \pm 97.7 \mathrm{Ba}$ & $60.3 \pm 25.8 \mathrm{Bb}$ & $59.5 \pm 28.8 \mathrm{Bb}$ & $38.3 \pm 19.4 \mathrm{Bb}$ & $81.9 \mathrm{C}$ \\
\hline Average & $168.2 a$ & $109.5 b$ & $96.2 b$ & $96.2 b$ & \\
\hline
\end{tabular}

Means followed by the same uppercase letter in columns and lowercase letter in rows do not differ significantly by Scott-Knott test $(P<0.05)$.

weight, regardless of the distance between the trap and the evaluated plant. The results obtained here indicate that the use of McPhail traps containing the attractive food can be used as a pest control strategy in maize providing a grain of fundamental quality for both the canning industry and the fresh market.

\section{Discussion}

Euxesta spp. can cause significant injuries that occur even when insecticides are used, and infestations in ears above
$30 \%$ usually result in batch rejection in the sweetcorn market for industrial processing (Cruz et al 2011; Kalsi 2011).

The reduction of damage caused by Helicoverpa larvae, one of the main insect pests of the sweet corn ear, as a consequence of the overall management of Lepidoptera through the release of the egg parasitoid Trichogramma pretiosum in the target area should also be considered as a factor influencing the lower damage index attributed to the corn ear fly. These flies frequently use the damage caused by other insects to increase their attack on corn cobs (Cruz et al 2011). According to Kalsi (2011) and Kalsi et al (2014), the

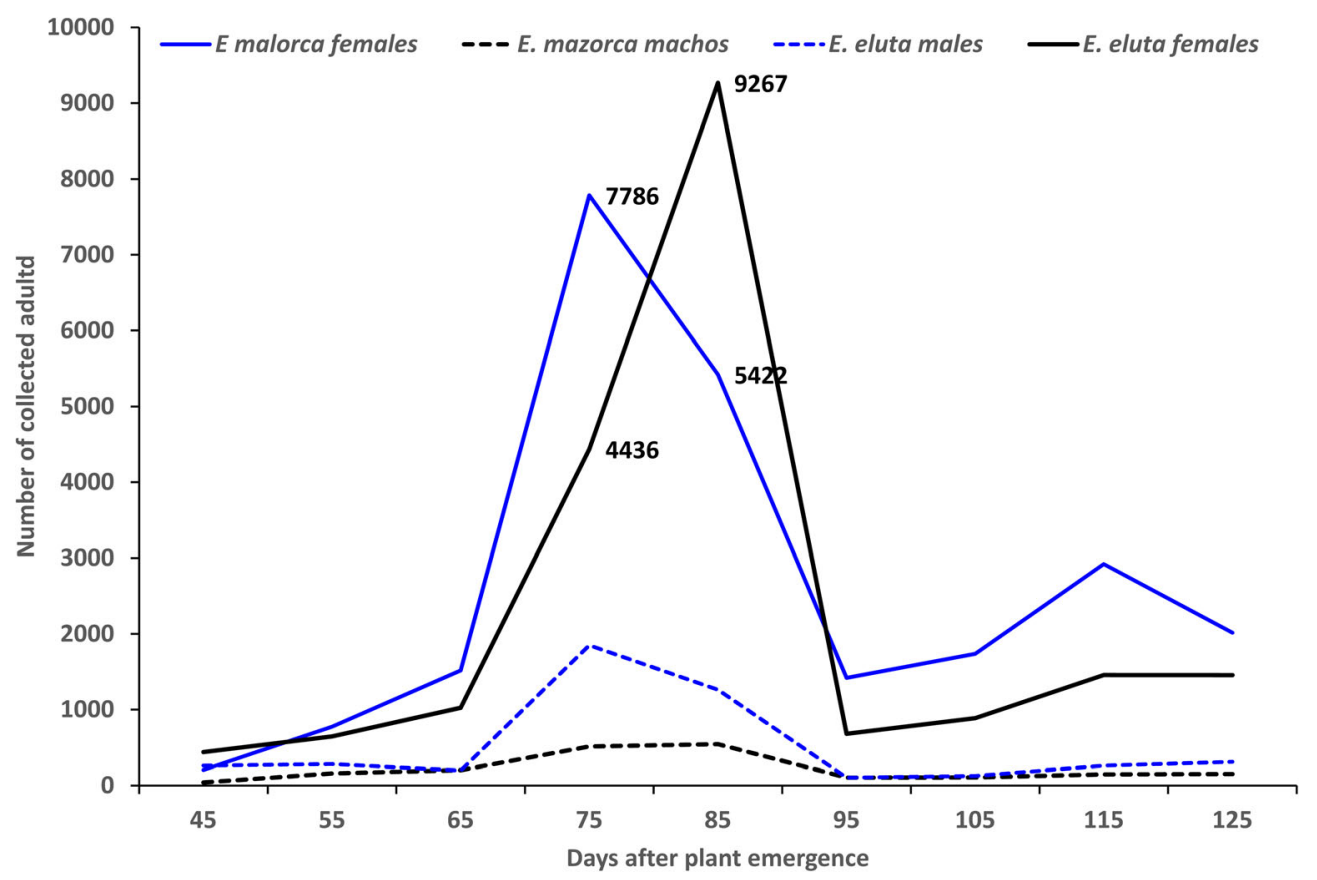

Fig 2 Total number of Euxesta mazorca and Euxesta eluta male and female adults collected in 12 McPhail-type traps, Sete Lagoas, Brazil. 
Table 4 Damage $( \pm S E)$ in the middle or at the tip of cobs (length of damage in centimeters) of sweet corn in function of a food attractant solution on McPhail traps used to monitor Euxesta spp. Sete Lagoas, Brazil.

\begin{tabular}{|c|c|c|c|c|c|c|}
\hline \multirow[t]{3}{*}{ Food attractant $(F A)+$ insecticide dose } & \multicolumn{3}{|c|}{ Damage in the middle of cobs $(\mathrm{cm})^{1}$} & \multicolumn{3}{|c|}{ Damage at the tip of cobs $(\mathrm{cm})^{1}$} \\
\hline & \multicolumn{6}{|c|}{ Trap distance $(\mathrm{m})$} \\
\hline & 1 & 10.2 & 15 & 1 & 10.2 & 15 \\
\hline FA & $1.7 \pm 1.1 \mathrm{Aa}$ & $1.6 \pm 1.1 \mathrm{Aa}$ & $1.8 \pm 0.8 \mathrm{Aa}$ & $1.1 \pm 0.2 \mathrm{Aa}$ & $0.8 \pm 0.3 A a$ & $0.8 \pm 0.2 \mathrm{Aa}$ \\
\hline $\mathrm{FA}+1.5 \mathrm{~mL}$ & $1.4 \pm 0.4 \mathrm{Aa}$ & $0.8 \pm 0.1 \mathrm{Aa}$ & $1.5 \pm 0.9 \mathrm{Aa}$ & $0.9 \pm 0.4 \mathrm{Aa}$ & $0.5 \pm 0.4 A a$ & $0.9 \pm 0.2 \mathrm{Aa}$ \\
\hline $\mathrm{FA}+2.25 \mathrm{~mL}$ & $1.3 \pm 0.4 \mathrm{Aa}$ & $1.2 \pm 0.6 \mathrm{Aa}$ & $1.1 \pm 0.1 \mathrm{Aa}$ & $0.9 \pm 0.4 \mathrm{Aa}$ & $1.1 \pm 0.5 \mathrm{Aa}$ & $0.7 \pm 0.2 \mathrm{Aa}$ \\
\hline $\mathrm{FA}+3.0 \mathrm{~mL}$ & $0.9 \pm 0.1 A a$ & $1.2 \pm 0.4 \mathrm{Aa}$ & $0.6 \pm 0.1 \mathrm{Aa}$ & $1.0 \pm 0.5 \mathrm{Aa}$ & $0.8 \pm 0.3 \mathrm{Aa}$ & $1.0 \pm 0.2 \mathrm{Aa}$ \\
\hline
\end{tabular}

${ }^{1}$ Means followed by the same uppercase letter in columns and lowercase letter in rows do not differ significantly by Scott-Knott test $(P<0.05)$.

decrease in $\mathrm{H}$. zea infestation results in less attraction and consequent reduction of the ear fly. In fact, adult females can easily enter the ears to feed and lay eggs after previous damage by corm earworm (Matrangolo et al 1998). Nuessly et al (2007) reported that ears containing damage caused by S. frugiperda on straw, style-stigma, and grains were more damaged by E. stigmatias larvae than ears without damage.

As already pointed out, corn silk fly is a limiting factor in the production of sweet corn, whether for in natura or processed consumption. Unfortunately, there is still little information about different biological aspects of this pest, including about the species that occur in Brazil. Among the few papers published in the country about this subject, almost all mention the presence of Euxesta eluta in corn crops, without, however, indicating any management strategy.
In a recent work, Cruz et al (2011) reported the presence of $E$. mazorca in the country. In this work, the authors demonstrated the feasibility of monitoring adult insects using McPhail-type traps containing food attractants, especially the hydrolyzed maize protein, Bio Anastrepha ${ }^{\circledR}$. Such a procedure has been used to monitor additional species (Lasa et al 2015, Owens et al 2017). As the genus Euxesta has similarities with insects belonging to other genera, especially those that encompass true fruit flies, the results demonstrated by Cruz et al (2011) and in this work suggest the possibility of using this technology in sweet corn production systems, although further studies are required. In this work, we distributed 12 traps in an approximate area of $8000 \mathrm{~m}^{2}$ containing about 35,000 plants. The total number of caught insects was 51,051 . Of those, 44,082 were females, directly responsible

Table 5 Cob weight, grain weight and cob length of sweet corn in function of food attractant solution on McPhail traps used to monitor Euxesta spp. Sete Lagoas, Brazil.

\begin{tabular}{|c|c|c|c|}
\hline \multirow[t]{2}{*}{ Food attractant $(F A)+$ insecticide dose } & \multicolumn{3}{|c|}{ Trap distance $(\mathrm{m})$} \\
\hline & 1 & 10.2 & 15 \\
\hline & \multicolumn{3}{|c|}{ Cob weight $(g)^{1}$} \\
\hline FA & $45.3 \pm 9 A a$ & $46.6 \pm 7 \mathrm{Aa}$ & $40.3 \pm 5 \mathrm{Aa}$ \\
\hline $\mathrm{FA}+1.5 \mathrm{~mL}$ & $41.8 \pm 3 \mathrm{Aa}$ & $41.6 \pm 4 \mathrm{Aa}$ & $43.9 \pm 6 \mathrm{Aa}$ \\
\hline $\mathrm{FA}+2.25 \mathrm{~mL}$ & $50.8 \pm 3 A a$ & $40.6 \pm 4 \mathrm{Aa}$ & $45.5 \pm 6 \mathrm{Aa}$ \\
\hline \multirow[t]{2}{*}{$\mathrm{FA}+3.0 \mathrm{~mL}$} & $45.6 \pm 5 A a$ & $40.3 \pm 6 \mathrm{Aa}$ & $47.1 \pm 6 \mathrm{Aa}$ \\
\hline & \multicolumn{3}{|c|}{ Grain weight $(g)^{1}$} \\
\hline FA & $28.6 \pm 6 \mathrm{Aa}$ & $30.1 \pm 4 \mathrm{Aa}$ & $26.1 \pm 2 \mathrm{Aa}$ \\
\hline $\mathrm{FA}+1.5 \mathrm{~mL}$ & $25.8 \pm 1 \mathrm{Aa}$ & $23.2 \pm 3 \mathrm{Aa}$ & $26.3 \pm 5 A a$ \\
\hline $\mathrm{FA}+2.25 \mathrm{~mL}$ & $30.13 \pm 1 \mathrm{Aa}$ & $23.4 \pm 3 \mathrm{Aa}$ & $26.4 \pm 4 \mathrm{Aa}$ \\
\hline \multirow[t]{2}{*}{$\mathrm{FA}+3.0 \mathrm{~mL}$} & $27.7 \pm 3 \mathrm{Aa}$ & $23.8 \pm 5 \mathrm{Aa}$ & $26.8 \pm 4 \mathrm{Aa}$ \\
\hline & \multicolumn{3}{|c|}{ Cob length $(\mathrm{cm})^{1}$} \\
\hline FA & $12.2 \pm 1 \mathrm{Aa}$ & $12.4 \pm 1 \mathrm{Aa}$ & $11.8 \pm 1 \mathrm{Aa}$ \\
\hline $\mathrm{FA}+1.5 \mathrm{~mL}$ & $11.6 \pm \mathrm{OAa}$ & $12.3 \pm \mathrm{OAa}$ & $11.8 \pm 1 \mathrm{Aa}$ \\
\hline $\mathrm{FA}+2.25 \mathrm{~mL}$ & $14.0 \pm 3 \mathrm{Aa}$ & $11.6 \pm \mathrm{oAa}$ & $11.9 \pm \mathrm{OAa}$ \\
\hline $\mathrm{FA}+3.0 \mathrm{~mL}$ & $12.0 \pm \mathrm{OAa}$ & $11.4 \pm \mathrm{oAa}$ & $11.9 \pm \mathrm{OAa}$ \\
\hline
\end{tabular}

${ }^{1}$ Means followed by the same uppercase letter in columns and lowercase letter in rows do not differ significantly by Scott-Knott test $(P<0.05)$. 
for the population growth of the pest and, therefore, for potential damages on the crop, initiated when laying eggs on the plants.

According to Frías (1978), E. eluta begins oviposition at 11.5 and 6.4 days after adult emergence at $16^{\circ}$ and $25^{\circ} \mathrm{C}$, respectively. Under these same conditions, the egg to adult cycle is 55.8 and $\mathbf{2 8 . 3}$ days. The insect lays eggs preferentially based on silks of more developed ears, in places protected by husk. The author also points out that oviposition can also occur in areas of fermentation caused by caterpillars, that is, at the tip of the cob; or in exit holes of developed caterpillars, usually in the middle or the base of the cob. According to Seal and Jansson (1978), E. stigmatias larvae have preference for the tip (58.8\%) than to the middle $(20.4 \%)$ and the base of the cob $(20.4 \%)$. On the other hand, the preferred place to become a pupa is mostly at the tip (83\%).

The number of eggs laid by $E$. eluta at an average temperature of $25^{\circ} \mathrm{C}$ can reach 450 per female in an adult life of about 40 days. The highest amount of eggs can be found between the 21st and 40th days (Frias 1981). Therefore, considering that the insect has been caught in the traps before oviposition, its removal from the maize area undoubtedly means an elimination of a very significant number of offspring that could cause significant damage to production.

Although Euxesta sp. is a pest that attacks corn ears at reproductive stages $\mathrm{R} 1$ (ear formation) and $\mathrm{R} 2$ (milky stage) (Ritchie and Hanway 1993; Nuessly and Hentz 2004), its presence was found well before those stages, when the maize was still in V10. Our finding differs from the report of Branco et al (1994), which shows the appearance of Euxesta at the flowering stage of silk emergence. This can facilitate its handling, especially using the removal technique presented here. According to Goyal et al (2012), the species Chaetopsis massyla (Walker), E. eluta, and E. stigmatias can complete the development in different species of cultivated plants including Brassica oleracea L., Capsicum chinense Jacquin, Capsicum annum L., Carica papaya L., Persea americana Mill., Raphanus sativus L., Saccharum officinarum L., and Solanum lycopersicum L. and weed species such as Amaranthus spinosus L., Portulaca oleracea L., Sorghum halepense L. and Typha spp.; all of which are commonly present in the vicinity of corn plantations, which may help to explain the occurrence of the fly in a new plantation almost immediately, even after prolonged absence of corn plants at the site.

The presence of both species with peaks in April shows the insects' adaptability to Brazil's winter condition and complements the information of Cruz et al (2011), who used traps in September-October when the pest was already present in the area. As already shown, we verified the occurrence of the pest in all sampling dates, with a high concentration of females in the period that goes from silk emergence to grain filling. The two species, E. mazorca and E. eluta, were present in the area from the time of the first sampling, meaning both are potential sweet corn pests.

The peak of captured insects, males and females of both $E$. eluta and E. mazorca, matches the period of flowering and grain filling of the maize crop, which can be explained by the female being attracted by the ear silk, preferred locus for oviposition. The presence of the insect, even in smaller numbers than the found at the peak of occurrence, can mean a potential problem to produce sweet corn, especially in the case of weekly production demanded by the processing industry.

The use of McPhail traps may be a suitable alternative to manage the population of E. eluta and E. mazorca in maize especially in the case of canned sweet corn, considering that the production is in relatively small areas and planted and staggered throughout the year. The experiment used 12 traps on approximately $0.8 \mathrm{ha}$. In addition, considering the relatively low cost of using the McPhail trap with the attractive food and higher relative value of sweet corn for the canning industry, and the lack of other efficient and environmentally friendly control techniques, the technology presented here is an interesting alternative to the Brazilian farm producing sweet corn.

The removal of Euxesta sp. females by using McPhail traps containing hydrolyzed corn protein (Bio Anastrepha ${ }^{\circledR}$ ) in the sweet corn production area to the point of significantly reducing the damage that would be caused by pest larvae suggests that the technique may be an important contribution to pest management, considering the low efficiency of spraying with chemicals and the risk of grain residues above legal limits.

Production of sweet corn for agribusiness in Brazil is generally staggered according to the size of the processing plant. Possible adjustments should be necessary especially for areas larger than the one used in the experiment. This fact is important because in Brazil, there is a great pressure from society against the use of chemicals in agriculture and especially when there are risks of residues in the human consumption product such as sweet corn. Similarly, there are also barriers to the consumption of genetically modified maize (Bt maize). However, even with these facts, a comparison of traps with other methods will serve to evaluate their usefulness as an important method of fly control in sweet corn.

For a planted area of 0.8 ha, the removal of 51,051 insects, most of them females, was enough to prevent damage to the ear, thus ensuring the quality of the product delivered to the processing industry. Without elimination of such females from the field, their offspring considering a fecundity of 450 eggs per female would certainly be very high. On the other hand, a low insect population in the field could be further, reduced by the presence of natural biological control agents such as the predator species Zelus longipes (L.) (Hemiptera: Reduviidae) and Orius insidiosus (Say) (Hemiptera: Anthocoridae) as reported by Kalsi et al (2014) and very common in Brazil. 
Funding Information This study was financially supported by the Sete Lagoas University Center, UNIFEMM, and CNPq.

\section{References}

Branco MC, Villas Boas GL, Reifschneider FJB (1994) Avaliação da resistência a Helicoverpa zea (Lepidoptera; Noctuidae) (Boddie) e Euxesta sp. (Diptera: Otitidae) em linhas de milho-doce. An Soc Entomol Bras 23:137-140

Ciampitti IA, Elmore RW, Lauer J (2011) Corn growth and development. Ames: lowa State University.

Cruz I, Figueiredo MLC, Oliveira AC, Vasconcellos CA (1999) Damage of Spodoptera frugiperda (Smith) in different maize genotypes cultivated in soil under three levels of aluminium saturation. Int J Pest Manag 45(4):293-296

Cruz I, Silva RB, Figueiredo MLC, Dias AMP, Del Sarto MCL, Nuessly GS (2011) Survey of ear flies (Diptera, Ulidiiae) in maize (Zea mays L.) and a new record of Euxesta mazorca Steyskal in Brazil. Rev Bras Entomol 55:102-108. https://doi.org/10.1590/Soo85-56262011000100016

Cruz I, Lopes SR, Figueiredo MLC, Viana PA, Mendes SM (2016) Controle biológico de pragas do milho-doce. In: Pereira Filho IA, Teixeira FF (eds) O cultivo do milho-doce, Brasília, Embrapa, pp 205-224 298p

Figueiredo MLC, Cruz I, Silva RB (2015) Biological control with Trichogramma pretiosum increases organic maize productivity by 19\%. Agron Sustain Dev 35:1175-1183. https://doi.org/10.1007/ s13593-015-0312-3

Frías DL (1978) Estudios ecológicos em Euxesta eluta y Euxesta annonae (Diptera, Otitidae). Agri Tec 38:109-115

Frias DL (1981) Diferencias de microhabitats entre Euxesta eluta y Euxesta annonae (Diptera, Otitidae). Agri Tec 41:89-94

Goyal G, Nuessly GS, Seal DR, Steck GJ, Capinera JL, Boote KJ (2012) Alternative plants for development of picture-winged fly pests of maize. Entomol Exper Appl 143:177-184

Huepe SG, Vargas HC, Frias DL, Bobadilla DG (1986) Estudio morfológico y ecologico de Euxesta eluta Loew y Euxesta mazorca Steyskal (Diptera: Otitidae) em cultivares de maíz em El Valle de Lluta, Arica. Rev Chil Ent 14:17-24

Kalsi M (2011) Potential predators of corn-infesting picture-winged flies (Diptera: Ulidiidae) in homestead, Florida: seasonal abundance, distribution and functional response. 114f. Master's degree Dissertation. Florida University

Kalsi M, Seal DR, Nuessly GS, Capinera JL, Martin CG (2014) Distribution of arthropod predators and their responses to Euxesta spp. (Diptera: Ulidiidae) in the laboratory and in corn fields in south Florida. Fla Entomol 97:911-920

Lasa R, Herrera F, Miranda E, Gómez E, Antonio S, Aluja M (2015) Economic and highly effective trap-lure combination to monitor the
Mexican fruit fly (Diptera: Tephritidae) at the orchard level. J Econ Entomol 108(4):1637-1645. https://doi.org/10.1093/jee/tov121

Matrangolo WJR, Cruz I, Della Lucia TMC (1998) Densidade populacional de Helicoverpa zea (Boddie) (Lepidoptera: Noctuidae) nas fases de ovo, larva e adulto em milho. An Soc Entomol Bras 1:21-28

Nuessly GS, Hentz MG (2004) Contact and leaf residue activity of insecticides against the sweet corn pest Euxesta stigmatias Lowe (Diptera; Otitidae). J Econ Entomol 97:496-502. https://doi.org/10.1603/00220493-97.2.496

Nuessly GS, Scully BT, Hentz MG, Beirifer R, Snook ME, Widstrom NW (2007) Resistance to Spodoptera frugiperda J.E. Smith (Lepidoptera: Noctuidae) and Euxesta stigmatias Loew (Diptera: Otitidae) in sweet corn derived from exogenous and endogenous genetic systems. J Econ Entomol 100:1887-1895

Owens D, Larsen N, Nuessly GS (2016a) Evaluation of two insecticide regimens for control of sweet corn ear pests, 2015. Arthropod Manag. Tests 41:tsw128. https://doi.org/10.1093/amt/tsw128

Owens D, Nuessly GS, Seal DR, Colquhoun TA (2016b) Variable pyrethroid susceptibility among the sweet corn infesting Ulidiidae (Diptera) in Florida and new baseline susceptibilities. J Econ Entomol 109:1283-1288. https://doi.org/10.1093/jee/tow054

Owens D, Cherry R, Karounos M, Nuessly GS (2017) Evaluation of lures for monitoring silk flies (Diptera: Ulidiidae) in sweet corn. Fla Entomol 100(2):251-256. https://doi.org/10.1653/024.100.0218

Painter RH (1985) Insetos em milho e teosinte na Guatemala. J Econ Entomol 48:36-42

Ritchie SW, Hanway JJ (1993) How a corn plant develops. lowa State University of Science and Technology, Ames, 26

Scott AJ, Knott MA (1974) Cluster analysis method for grouping means in the analysis of variance. Biom 30:507-512. https://doi.org/10.2307/ 2529204

Seal DR, Jansson R (1978) Biology and management of corn-silk fly, Euxesta stigmatias Loew (Diptera Otitidae), on sweet corn in Southern Florida. Proc Fla State Hort Soc 102:370-373

Sistema SISVAR para análises estatísticas (2017) Available online http:// www.dex.ufla.br/ danielff/programas/sisvar.html. Accessed 24/05/ 2017

Steyskal GC (1968) Family Otitidae (Ortalidae: including Pterocallidae, Ulidiidae). In: Vanzolini PE, Papavero N (eds) A catalogue of the Diptera the Americans South of the United States. Secretaria de Agricultura, São Paulo, 54

Steyskal GC (1974) Euxesta mazorca, new species, associated with ears of maize in South America (Diptera .Otitidae). Proc Biol Soc Wash 87: 73-86

Publisher's Note Springer Nature remains neutral with regard to jurisdictional claims in published maps and institutional affiliations. 